15. Long-term effect of a single potassium fertilization on ${ }^{137} \mathrm{Cs}$ levels in plants and fungi in a boreal forest ecosystem / [K. Rosén, M. Vinichuk, I. Nikolova, K. Johanson] // J. Environ. Radioact.- 2011. - V. 102(2). P. 178-184.

16. Long-term reduction in ${ }^{137} \mathrm{Cs}$ concentration in food crops on coral atolls resulting from potassium treatment / [W. L. Robison, E. L. Stone, T. F. Hamilton, C. L. Conrado] // J. Environ. Radioact. - 2006. - V. 88. - P. $251-266$.

Мандро Юрий, Виничук Михаил. Древесная зола как средство снижения перехода ${ }^{137}$ Cs из почвы в растения рябины обыкновенной (Sorbus aucuparia L.) и крушины ломкой (Rhamnus frangula L.) в лесных экосистемах Полесья Украины. Заложен научный опыт в загрязненном радионуклидами лесу (примерно 70 км от Чернобыля) с применением калийсодержащих мелиорантов (древесный пепел, $\mathrm{KCl}$ ) с целью исследования их способности влиять на поступление ${ }^{137} \mathrm{Cs}$ в растения, типичные для лесных экосистем Полесья Украины. Показано влияние древесной золы на переход ${ }^{137} \mathrm{Cs}$ из почвы в молодые побеги и листья рябины обыкновенной (Sorbus aucuparia L.) и крушины ломкой (Rhamnus frangula L.) в течение периода вегетации на радиоактивно зараженной в результате аварии на Чернобыльской АЭС территории. Проведен сравнительный анализ эффективности применения древесного пепла, калийного удобрения и их сочетания как средств снижения перехода радиоцезия из почвы в растения в первый и второй год после внесения. Проанализированы различия в скорости и качестве реакции исследуемых древесных пород на внесённые удобрения, которая очевидно связана с морфологическими особенностями растений. Отображены особенности накопления ${ }^{137} \mathrm{Cs}$ вышеупомянутыми древесными породами в течение вегетационного периода на варианте без внесения удобрений («Контроль»).

Ключевые слова: Sorbus aucuparia L., Rhamnus frangula L., ${ }^{137}$ Cs, период вегетации, древесный пепел, калийное удобрение.

Mandro Yurii, Vinichuk Mykhailo. Wood ash as a Means of Reducing ${ }^{137}$ Cs Transfer From Soil to Plants Ofrowan (Sorbus Aucuparia L.) and Buckthorn (Rhamnus Frangula L.) in Forest Ecosystems of Ukrainian Polissya. The scientific experiment was laid in contaminated by radionuclides forest (about $70 \mathrm{~km}$ from Chernobyl) with applying potassium-containing fertilizers (wood ash, $\mathrm{KCl}$ and $\mathrm{mix}$ of them) to investigate their ability to influence on ${ }^{137} \mathrm{Cs}$ uptake by plants typical for the forest ecosystems of Ukrainian Polissya. The effect of wood ash on ${ }^{137} \mathrm{Cs}$ transfer from soil to young shoots and leaves of rowan (Sorbus aucuparia L.) and buckthorn (Rhamnus frangula L.) during the growing season in the radioactively contaminated area (as a result of the accident at the Chernobyl nuclear power plant) is represented. A comparative analysis of the efficiency of wood ash, potasium fertilizer, and combinations thereof, as a means to reduce radiocaesium soil-to-plants transfer during the first and second year after the application was made. The differences in the speed and quality of response of studied trees on applied fertilizers, which are obviously related to the morphological features of the plants, were analyzed. The features of ${ }^{137} \mathrm{Cs}$ uptake by mentioned above tree species during the growing season on the treatment without any applied fertilizers («Control») are shown.

Key words: Sorbus aucuparia L., Rhamnus frangula L., ${ }^{137}$ Cs, growing season, wood ash, potash fertilizer.

Стаття надійшла до редколегії 06.09.2015 p.

\title{
Зміни клімату як загроза для флори водних макрофітів Північного Поділля
}

У статті досліджено взаємозв' язок між змінами клімату та видовим різноманіттям флори макрофітів Північного Поділля. Проаналізовано дію кліматичних чинників на зміну кількості водойм (на прикладі Кременецького району). Запропоновано прогноз змін флори макрофітів Північного Поділля. Порівняно гідрофільні флори України й Польщі за допомогою визначення коефіцієнтів подібності.

Ключові слова: зміни клімату, динаміка, порівняння, гідрофільна флора, Північне Поділля, Кременецький район.

Постановка наукової проблеми та її значення. Унаслідок антропогенної діяльності та глобальних змін клімату водні ресурси України й, зокрема, Північного Поділля перебувають під загрозою

(C) Михалюк I., Чопик В., 2015 
зникнення. Головними факторами такого впливу є зменшення кількості опадів та зростання інтенсивності випаровування як із поверхні суші, так і з водного дзеркала водойм. Процес глобального потепління в поєднанні з впливом нераціональної водогосподарської діяльності людини зумовлюють зменшення водності річок і ставів та призводять до їх обміління [1]. Це явище і його ймовірні наслідки досить широко висвітлюються як у популярній, так і в науковій літературі, часто обговорюються в засобах масової інформації, однак серед вітчизняних науковців окреслена проблематика ще не отримала належного висвітлення [3].

На території України проблема глобальних змін клімату досить гостро постала в останні 2025 років. Обмежена кількість опадів зумовлює зниження рівня води в річках. Упродовж останніх 40 років значно зменшилася глибина Південного Бугу й деяких приток Дніпра. За даними Тернопільського обласного центру з гідрометеорології, у 2015 р. на Дністровському, Київському та Канівському водосховищах відзначається найменший за період їх експлуатації приплив води (відповідно, із 1985, 1965 і 1973 рр.). У Ладизькому водосховищі рівень води знизився майже на 1,5 м. Водність таких річок, як Південний Буг, Синюха та Рось, у серпні впала нижче критеріїв маловоддя ${ }^{1}$. Дуже низька водність утримується у верхів'ї Прип'яті, на деяких ділянках Західного Бугу, Пруту, Серету, Десни [9].

Як зазначають Н. С. Лобода й Ю. В. Божок, унаслідок антропогенної діяльності та кліматичних змін, під загрозою знищення перебувають водні ресурси Тилігульського лиману [5].

Посуха впливає як на поверхневі, так на підземні води, та може призвести до дефіциту води, погіршення іiі якості, порушення стану прибережного середовища й призупинення рекреаційної діяльності [1]. Значний вплив посухи відображається на характеристиках мінімального стоку річок, оскільки за умов довготривалої відсутності опадів стік річок формується лише за рахунок надходження до русла підземних вод із водоносних горизонтів. Зі свого боку, запаси підземних вод, які живлять річку в період межені, за наявності метеорологічної посухи, також виснажуються й сприяють їі пересиханню [6].

Мета роботи - порівняти гідрофільні флори різних регіонів України та Польщі за допомогою коефіцієнтів подібності, дослідити вплив глобальних змін клімату на флору макрофітів Північного Поділля, проаналізувати дію кліматичних чинників на кількість водойм (на прикладі Кременецького p-ну), запропонувати прогноз змін флори макрофітів Північного Поділля

Матеріали та методи досліджень. В основу роботи покладено матеріали польових досліджень, проведених нами впродовж 2010-2015 pр. Дослідження флори здійснювалося рекогносціювальномаршрутно-експедиційним методом. У ньому використано низку традиційних для ботанічних досліджень математичних методів. Під час порівняння гідрофільних флор користувалися повними флористичними списками. Для порівняння флор між собою ми використовували коефіцієнт видової подібності Жаккара $(\mathrm{Kj})$ й індекс подібності Серенсена $(\mathrm{QS})$. Для аналізу кліматичних показників користувалися даними Кременецької метеорологічної станції.

Виклад основного матеріалу й обгрунтування отриманих результатів дослідження. За фізикогеографічним районуванням територія Північного Поділля займає вододільну частину Подільської височини. На півночі вона відмежована Малим Поліссям, на південному заході - Товтровим пасмом. В адміністративному відношенні східна межа Північного Поділля майже точно збігається з кордоном Хмельницької області на відрізку Полонне-Хмельник, а південна - по лінії Хмельник - Стара Синява - Красилів - Хмельницький - Сатанів. Територія дослідження лежить у межах Волино-Подільського артезіанського басейну, де беруть свій початок притоки Прип'яті (річки Вілія, Горинь, Хомора, Случ, Іква), Південного Бугу (Вовк, Бужок) та Дніпра (Смотрич, Збруч). Річки характеризуються пологими берегами, повільною течією, слабовиробленими долинами, заболоченими заплавами. У районі дослідження виявлено багато штучних водойм - ставків і водосховищ, які створені на річках, а також у балках, де протікають водотоки. Майже в кожному населеному пункті є став, який слугує для розведення риби та водоплавної птиці.

1 у довідкових джерелах поняття «маловоддя» розуміють як аномальне явище, спричинене тривалою атмосферною посухою, яка характеризується нестачею опадів, порівняно з нормою, упродовж тривалого часу при підвищеній температурі [14]. 
За даними Тернопільського й Хмельницького управління водними ресурсами, на території Північного Поділля нараховується 1091 водойма загальною площею водного дзеркала 7021,48 га [12, 13]. У Кременецькому районі станом на 2012 р. була 61 водойма загальною площею водного плеса 573,49 га. У 2015 р., за даними Тернопільського обласного управління водними ресурсами, на Кременеччині нараховується 52 ставки, п'ять джерел та три річки [12]. Більшість ставів розміщені в руслах річок $\mathrm{i}$ наповнюються за рахунок місцевого стоку. На багатьох із них обладнано водоскиди автоматичної дії або греблі, які в більшості перебувають у зруйнованому стані й потребують ремонту. Ставки використовуються переважно для риборозведення, потреб населення та сільського господарства.

В останні десятиріччя на досліджуваній території простежено стійке підвищення температури повітря впродовж усього року, що супроводжується й зміною режиму зволоження. Річна сума опадів змінилася несуттєво, але спостерігається ії перерозподіл між сезонами й місяцями. Найбільш посушливі місяці - травень, серпень та вересень. На рис. 1 зображено середньомісячні суми опадів за 65 років, із 1946 до 2009 pp. Найменшою кількістю опадів (331 мм) характеризується 1961 р. (точка 17 на рис. 1). За максимальною кількістю опадів можна відзначити - 1974 (927 мм), 1998 (924 мм), 2001 (976 мм) та 2008 (977 мм) роки.

Аналіз середньомісячної кількості опадів за час дослідження засвідчує їх зменшення, а саме: 2012 p. - 738 мм, 2013 р. - 721 мм; 2014 р. - 529 мм. За перше півріччя 2015 р. - 228,9 мм, у тому числі за липень - 39,6 мм [9].

Досліджуючи вплив кліматичних чинників на стан водойм Північного Поділля, ми встановили, що за 2010-2015 pр. на території Кременецького р-ну повністю висохли стави в селах Сарий Олексинець (9,99 га), Іловиця (2,33 га), Чугалі (1,15 га) та Малі Бережці $(0,40$ га). Невеликий став кар'єрного типу в М. Бережцях пересох на $80 \%$, хоча у 2011 р. рівень води в ньому сягав 1,3 м. Сьогодні там простежено його активне заростання та перетворення в болото.

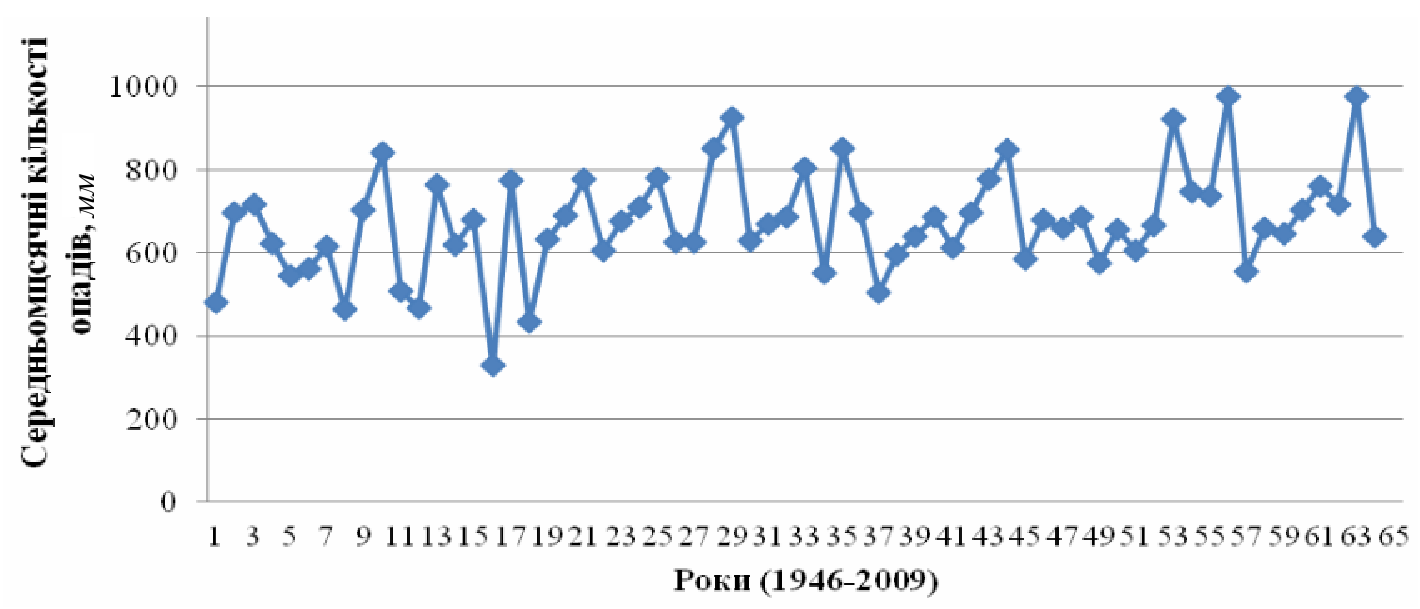

Рис.1. Середньомісячна кількість опадів у Кременецькому районі за 65 років

Значно обміліли (інколи на 50\%) стави в селах Рудка (39,64 га), Дунаїв (5,68 га), Куликів (1,0 га), Іванківці (7,76 га). У с. Горинка пересохли копанки, які використовували для розведення риби. У межах указаного населеного пункту в кількох місцях, пересохла р. Горинька (притока Горині) загальною довжиною 10 м. (рис. 2). У результаті недбалої діяльності людини та кліматичних чинників під загрозою зникнення перебуває потік Ірва у м. Кременець.

Така напружена ситуація на водоймах району спричинена багаторічними природними процесами та антропогенним тиском, а посушливий 2015 р. став завершальним етапом. Особливістю погодних умов у весняно-літній період 2015 р. $є$ нехарактерний для території дослідження розподіл опадів, що впливав на водний режим річок. Найменшу кількість опадів, лише 50-70\%, простежено в Північній частині району, хоча на цій території завжди відзначали достатню зволоженість [9]. 


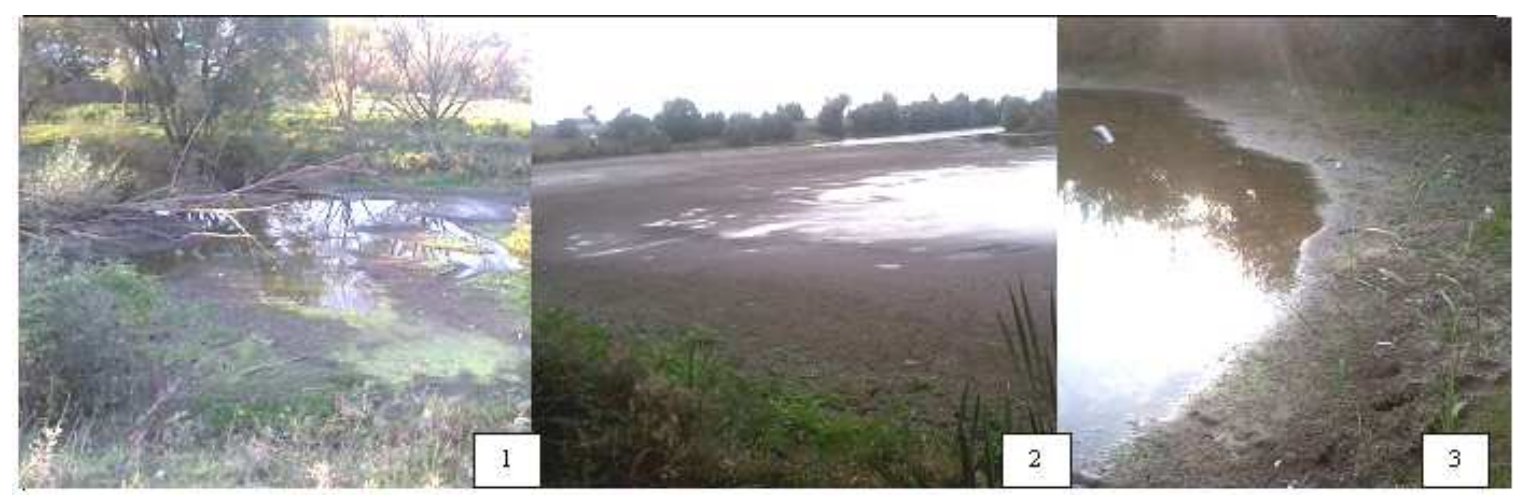

Рис. 2. Рівень води у водоймах Кременеиького р-ну у 2015 p. Цифрами позначено: 1 - копанка на р. Горинька, 2 - став у с. Дунаїв, 3 - ставок у с. В. Бережці

На тих водоймах, де рівень води близький до мінімального, стави в с. Горинка, Великі Бережці, Лосятин, Старий Тараж, Сапанів, Лішня ми спостерігали видове збіднення флори макрофітів. На ділянках відступу води на місці типових водних з'являлися прибережні види рослин. Процес заміни одних угруповань іншими проходить поступово, у міру зменшення водного дзеркала. Такі види макрофітів, як Glyceria maxima (Hartm.) Holmb., Typha angustifolia L., T. latifolia L., Poa palustris L., Sagittaria sagittifolia L., Butomus umbellatus L., на початкових етапах спостереження займали прибережні ділянки навколо водойми (2-2,5 м), а центральну частину водного плеса - водні макрофіти, занурені у воду - Nuphar lutea (L.) Sm., Potamogeton natans L., P. perfoliatus L. Згодом, коли рівень води істотно зменшився, нові території заселили болотні види Acorus calamus L., Calla palustris L., Iris pseudacorus L., Bidens cernua L. (рис. 3).

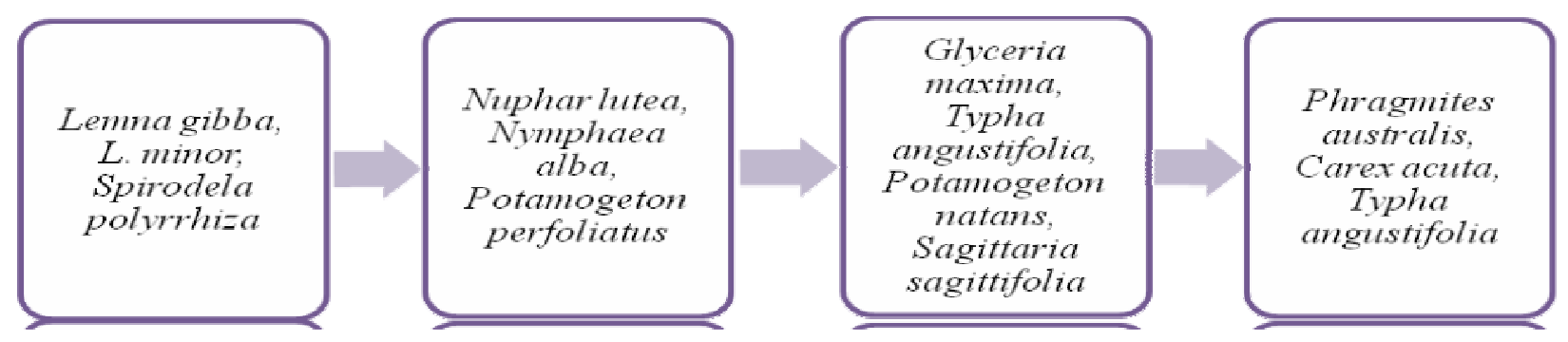

Рис. 3. Схема змін водних макрофітів, спричинених зниженням рівня води

Такий процес поступової заміни гідатофітів мезофітами засвідчує ксерофітизацію середовища.

У середньому, за нашими підрахунками, на території Кременецького району з 2012 до 2015 р. висохло дев'ять водойм, серед яких чотири перебувають без води багато років. Переважно пересихають природні й заплавні стави, які не використовуються для потреб господарства. Натомість утворюються нові штучні водоймища, наповнення яких відбувається не щорічно, а лише в багатоводні роки.

3 огляду на таку динаміку змін, ми можемо констатувати, що в середньому за 10 років пересихають або тривалий час перебувають без води три водойми. Процес висихання здебільшого залежить від погодних умов (довгий час без опадів), екологічного стану водойми, антропогенного тиску та нераціонального використання водних ресурсів. Якщо такий антропогенний вплив і кліматичнопогодні умови спостерігатиметься й надалі, то через 150 років (у 2165 р.) на території Кременецького р-ну може залишитися лише сім водойм.

Отже, ураховуючи динаміку водойм у Кременецькому районі, ми можемо припустити, що на території Північного Поділля ситуація буде подібною й через 200 років тут висохне 60 водойм. А до середини XXIV ст., у 2380 р., на досліджуваній території може залишиться всього 11 водойм.

Унаслідок зменшення рівня води у водоймах досліджуваної території спостерігається не лише їх пересихання, а й відбуваються зміни в рослинних угрупованнях. Гідрофільним флорам, як і будьяким іншим, властиві постійні динамічні процеси - одні види зникають, інші з'являються. Такою $є$ 
також флора Північного Поділля - іiі таксономічний склад $є$ відносним у кожному конкретному випадку, найбільш екологічно вразливі види зникають, а їхнє місце займають екологічно витриваліші «пристосуванці».

Досліджуючи флору водойм Північного Поділля, виявили чотири, можливо, зниклих види Caldesia parnassifolia (L.) Parl., Cladium mariscus (L.) Pohl, Hottonia palustris L., Scheuchzeria palustris L. Ще 15 гідрофільних видів трапляються дуже рідко. Це такі макрофіти, як Salvinia natans (L.) All., Ranunculus polyphyllus Waldst. et Kit. ex Willd., Nasturtium officinale W.T. Aiton, Naumburgia thyrsiflora Rchb., Aldrovanda vesiculosa L., Pinguicula vulgaris L., Callitriche stagnalis Scop., Potamogeton acutifolius Link, P. alpinus Balb., Hammarbya paludosa (L.) Kuntze, Juncus tenuis Wild., Carex davalliana Sm., Schoenus ferrugineus L., Calla palustris L., Wolffia arrhiza (L.) Horkel ex Wimm. За власними спостереженнями, згідно з гербарними зразками та літературними джерелами, для цих видів на досліджуваній території відомо менше п’яти достовірних місцезнаходжень. Вони перебувають під загрозою зникнення.

Динамічні процеси флори характеризуються не лише зникненням, але й появою нових видів. На території Північного Поділля нами виявлено два нових місцезростання Wolffia arrhiza - p. Горинька та р. Вілія, які раніше не згадувались у літературі для досліджуваного регіону. В «Определителе высших растений Украины» відзначено, що цей вид розповсюджений у стоячих водоймах Лісостепу, рідше - на Поліссі [10]. Північно-західна межа поширення W. arrhiza на території України відзначена в старицях Дністра на території Чайковецького гідрологічного заказника. Також наявні відомості про знахідку цього виду на території Малого Полісся [8].

Оптимальними умовами зростання $W$. arrhiza у Лісостеповій та Степовій зонах України $є$ прісноводні водойми з незначним коливанням рівня води, слаболужною або нейтральною реакцією середовища, мулистими донними відкладами 3 товщею води 25-50 см [7]. Тому, ураховуючи вищенаведене, ми можемо припустити, поступову уніфікацію екологічних умов різних зон, що сприяє поширенню видів на нові території й прямо або опосередковано підтверджує зміну клімату в бік потепління.

Щоб простежити та спрогнозувати зміни у флорі водних макрофітів Північного Поділля, ми порівняли ії з флорами Західного Поділля, Лісостепу України, басейну верхньої частини Дністра, Пруту та Західного Бугу й флорою водойм і боліт Польщі $[2 ; 4 ; 15 ; 16]$. Це дасть змогу підтвердити або спростувати наше твердження, що подібність гідрофільних флор пов'язана зі стабільним мікрокліматом водного середовища.

Для виявлення тенденцій трансформації макрофітів використовували метод порівняння флористичних списків вищезазначених флор. Для цього ми відібрали 10 модельних родин, які найкраще характеризують кожну з порівнюваних флор (табл. 1).

Таблиця 1

Видова різноманітність провідних родин порівнюваних флор

\begin{tabular}{|c|c|c|c|c|c|}
\hline Флора & $\begin{array}{l}\text { Північне } \\
\text { Поділля }\end{array}$ & $\begin{array}{c}\text { Західне } \\
\text { Поділля }\end{array}$ & $\begin{array}{c}\text { Басейни верхньої } \\
\text { частини Дністра, } \\
\text { Пруту та } \\
\text { Західного Бугу }\end{array}$ & $\begin{array}{l}\text { Лісостеп } \\
\text { України }\end{array}$ & Польща \\
\hline \multirow{10}{*}{ 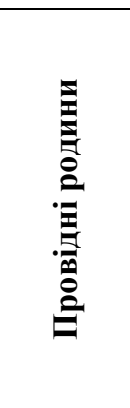 } & Cyp. $^{15}$ & Cyp. $^{23}$ & Cyp. $^{13}$ & Cyp. $^{40}$ & Cyp. $^{31}$ \\
\hline & Pot. & Pot. $^{1 /}$ & Pot. ${ }^{\text {II }}$ & Poa. $^{20}$ & Pot. $^{\top}$ \\
\hline & Poa. ${ }^{9}$ & Poa. $^{13}$ & Poa. $^{10}$ & Pot. $^{18}$ & Api. ${ }^{6}$ \\
\hline & Ran. $^{\prime}$ & Ran. $^{8}$ & Ran. $^{9}$ & Ast. $^{12}$ & Scr. ${ }^{6}$ \\
\hline & Ali. $^{3}$ & Api. ${ }^{3}$ & Pol. $^{\top}$ & Api. $^{10}$ & Orch. $^{6}$ \\
\hline & Lem. $^{5}$ & Scr. ${ }^{2}$ & Jun. ${ }^{6}$ & Ran. $^{9}$ & Ran. \\
\hline & Scr. ${ }^{5}$ & Lem. ${ }^{5}$ & Api. & Scr. ${ }^{8}$ & Lem. ${ }^{5}$ \\
\hline & Bra. $^{4}$ & Ali. ${ }^{3}$ & Spa. ${ }^{5}$ & Orch. $^{8}$ & Spa. \\
\hline & Api. $^{4}$ & Call. $^{4}$ & Bra. $^{5}$ & Bra.' & Poa. ${ }^{4}$ \\
\hline & Ast. $^{4}$ & Typ. ${ }^{4}$ & Lem. ${ }^{4}$ & Jun. ${ }^{5}$ & Ali. $^{4}$ \\
\hline Разом & 70 & 91 & 75 & 137 & 79 \\
\hline
\end{tabular}

Примітка. Родини: Сур. - Cyperaceae, Pot. - Potamogetonaceae, Poa.- Poaceae, Pol. - Polygonaceae, Ali. Alismataceae, Lem. - Lemnaceae, Ran. - Ranunculaceae, Bra. - Brassicaceae, Api. - Apiaceae, Scr. - Scrophulariaceae, Ast. - Asteraceae, Orch. - Orchidaceae, Jun. - Juncaceae, Spa. - Sparganiaceae, Call. - Callitrichaceae, Typ. - Typhaceae, Lam. - Lamiaceae. Число видів у родині вказано знаком степеня. 
Як видно $з$ табл. 1., у всіх порівнюваних флорах найбагатшою є родина Cyperaceae, далі Potamogetonaceae та Poасеае. Інші родини розміщені в різних послідовностях.

Аналіз спорідненості гідрофільних флор можливий лише з погляду теорії множин. Для цього найбільш математично доцільне застосування коефіцієнта видової подібності Жаккара $\left(\mathrm{K}_{\mathrm{j}}\right)$ та індексу подібності Серенсена (QS) [11].

$$
K_{J}=\frac{c}{a+b-c}
$$

де $a$ - кількість видів у провідних родинах першої флори, $b$ - кількість видів у провідних родинах другої флори, $c$ - кількість видів, які є спільними для порівнюваних флор.

$$
Q S=\frac{2 C}{A+B},
$$

де $A$ і $B$ - число видів у першій і другій флорі, $C$ - кількість видів, які спільні для двох флор.

У дослідженні ми використали два вищенаведені індекси, які останнім часом широко представлені в ботанічних дослідженнях та є простими й зручними для розрахунків. Формула Жаккара більш пропорційна, оскільки отримані за допомогою неї коефіцієнти відображають достовірніші результати подібності флор. Результати, отримані за формулою Серенсена, є відносними величинами. Коефіцієнт Жаккара характеризується більшою амплітудою числових значень і має більшу диференціальну силу при середніх і високих показниках подібності (понад 30 \%). Натомість індекс подібності Серенсена практичний при порівняні двох флор із незначною подібністю [11].

Для 3'ясування зв'язків гідрофільних флор складено списки з 10 провідних родин флори та обчислено для кожної пари об'єктів значення коефіцієнта подібності Жаккара та індекс подібності Серенсена. Показники попарних порівнянь записано в матриці подібності, де порівнювані флори розміщені по рядках і стовпцях, а значення подібності між ними вказуються на їх перетині. У чисельнику подано коефіцієнт Жаккара; у знаменнику - коефіцієнт Серенсена (табл. 2).

Таблиия 2

\begin{tabular}{|c|c|c|c|c|c|}
\hline Гідрофільні флори & $\begin{array}{c}\text { Північне } \\
\text { Поділля }\end{array}$ & $\begin{array}{c}\text { Західне } \\
\text { Поділля }\end{array}$ & $\begin{array}{c}\text { Басейни верхньої } \\
\text { частини Дністра, } \\
\text { Пруту та Західного } \\
\text { Бугу }\end{array}$ & $\begin{array}{l}\text { Лісостеп } \\
\text { України }\end{array}$ & Польща \\
\hline $\begin{array}{l}\text { Північне } \\
\text { Поділля }\end{array}$ & $\frac{1}{1}$ & $\frac{0,343}{0,510}$ & $\frac{0,450}{0,621}$ & $\frac{0,398}{0,570}$ & $\frac{0,354}{0,537}$ \\
\hline $\begin{array}{c}\text { Західне } \\
\text { Поділля }\end{array}$ & $\frac{0,343}{0,510}$ & $\frac{1}{1}$ & $\frac{0,338}{0,494}$ & $\frac{0,325}{0,491}$ & $\underline{0,232}$ \\
\hline $\begin{array}{c}\text { Басейни верхньої } \\
\text { частини Дністра, } \\
\text { Пруту та Західного } \\
\text { Бугу }\end{array}$ & $\frac{0,450}{0,621}$ & $\frac{0,338}{0,494}$ & $\frac{1}{1}$ & $\frac{0,341}{0,509}$ & $\frac{0,318}{0,482}$ \\
\hline Лісостеп України & $\frac{0,398}{0,570}$ & $\frac{0,325}{0,491}$ & $\frac{0,341}{0,509}$ & $\frac{1}{1}$ & $\frac{0,325}{0,491}$ \\
\hline Польща & $\underline{0,354}$ & $\frac{0,232}{0,377}$ & $\frac{0,318}{0,482}$ & $\frac{0,325}{0,491}$ & $\frac{1}{1}$ \\
\hline
\end{tabular}

Матриці видової подібності Жаккара та Серенсена в гідрофільних флорах України й Польщі

Як видно з табл. 2, видова подібність гідрофільних флор досліджуваних регіонів менша за 1 , переважають середні значення. Діапазон варіювання значень коефіцієнта Жаккара в матриці становить $0,232 \leq \mathrm{K}_{\mathrm{J}} \geq 0,450$, середнє значення коефіцієнта $\mathrm{K}_{\mathrm{J}} \mathrm{cp}=34,1 \%$, що свідчить про незначний рівень схожості гідрофільних флор. Діапазон значень індексу Серенсена в матриці становить $0,377 \leq$ $\mathrm{QS} \geq 0,621$, середнє значення індексу QS cp $=49,9 \%$, що вказує на середній рівень схожості флор.

Максимальні значення коефіцієнта Жаккара та індексу Серенсена маємо для однієї пари порівнюваних флор - Північного Поділля й басейнів верхньої частини Дністра, Пруту та Західного Бугу $\left(\mathrm{K}_{\mathrm{J}}=0,450\right.$, або $45 \%$; $\mathrm{QS}=0,621$, або 62,1\%). Найменш подібними між собою за двома 
коефіцієнтами є флори Західного Поділля та Польщі - $\mathrm{K}_{\mathrm{J}}=0,232$, або 23,2 \%, QS = 0,377, або 37,7 \%, що є закономірним відображенням їхньої просторової відокремленості.

Подібність флори водних макрофітів Північного Поділля й басейнів верхньої частини Дністра, Пруту та Західного Бугу пояснюється близьким географічним розміщенням цих флор на території України. Зі свого боку, флора басейнів верхньої частини Дністра, Прутй й Західного Бугу відзначається високим показником коефіцієнтів порівняння з флорою Лісостепу України $\left(\mathrm{K}_{\mathrm{J}}=0,341\right.$, або $34,1 \%$; $\mathrm{QS}=0,509$, або 50,9\%), що засвідчує їх близьку спорідненість.

Висновки та перспективи подальшого дослідження. У результаті наших досліджень установлено, що на території Північного Поділля простежено стійке підвищення температури повітря, що супроводжується зменшенням кількості опадів. Така ситуація провокує зниження рівня води у водоймах, а в деяких випадках - їх пересихання. Тому ми можемо припустити, що через 200 років на досліджуваній території пересохне 60, а до 2380 р. залишиться всього 11 водойм.

За результатами обчислень, здійснених за формулами Жаккара й Серенсена, можемо стверджувати, що гідрофільні флори, які розміщуються географічно близько одна до одної, відзначаються високими показниками подібності. Це пояснюється однаковими екологічними та кліматичними умовами й здатністю видів легко мігрувати на невеликі відстані, що в майбутньому можуть спричинити «злиття» всіх гідрофільних флор.

Для збереження природних ресурсів флори макрофітів Північного Поділля рекомендуємо оптимізувати розміщення та експлуатацію штучних водойм.

\section{Джерела та література}

1. Актуальные проблемы лиманов северо-западного Причерноморья / [под ред. Ю. С. Тучковенко, Е. Д. Гопченко]. - Одесса : ТЭС, 2012. - 224 c.

2. Борсукевич Л. М. Вища водна рослинність басейнів верхньої течії Дністра, Прута та Західного Бугу : дис. ... канд. біол. наук : 03.03.05 / Борсукевич Любов Миронівна. - К., 2010. - 507 с.

3. Кобів Ю. Й. Глобальні кліматичні зміни як загроза видовій біорізноманітності високогір'я Українських Карпат / Ю. Й. Кобів // Укр. ботан. журн. - 2009. - Т. 66, № 4. - С. 541-465.

4. Козам М. І. Вища водна рослинність Західного Поділля: синтаксономія, антропогенна динаміка, охорона : [монографія] / М. І. Козак. - Кам’янець-Подільський : ПП «Медобори-2006», 2012. - 268 с.

5. Лобода Н. С. Оцінка водних ресурсів річок басейну Тилігульського лиману в умовах змін глобального клімату / Н. С. Лобода, Ю. В. Божок // Гідрологія, гідрохімія і гідроекологія. - 2014. - Т. 1 (32). C. 32-40.

6. Лобода Н. С. Шляхи визначення можливої гідрологічної посухи за метеорологічними даними в умовах змін клімату для річок північно-західного Причорномор'я / Н. С. Лобода, Ю. В. Божок // Геополітика та екогеодинаміка регіонів : наук. журн. - Сімферополь, 2014. - Т.10. - Вип. 1 - С. 281-289.

7. Макрофиты - индикаторы изменений природной среды. / [Д. В. Дубына, С. М. Стойко, К. М. Сытник и др.]. Киев : Наук. думка, 1993. - С. 386-388.

8. Михалюк I. M. Знахідка Wolffia arrhiza (L.) Horkel ex Wimmer на півночі Тернопільської області / I. М. Михалюк // Наукові записки Тернопільського нац. пед. ун-ту ім. Володимира Гнатюка. - Серія : Біологія. - 2011. - № 1 (46). - С. 24-27.

9. Оперативна інформація Тернопільського обласного центру з гідрометеорології, № 36.04/10/673 від 02.09.2015 p.

10. Определитель высших растений Украины / [ Д. Н. Доброчаєва, М. И. Котов, Ю. Н. Прокудик и др.]. Киев : Наук. думка, 1987. - 548 с.

11. Сидоренко Е. В. Методы математической обработки в психологии / Е. В. Сидоренко. - СПб. : ООО Речь, 2002. -350 с.

12. Тернопільське обласне управління водних ресурсів [Електронний ресурс] : [Веб-сайт]. - Режим доступу : - http://maps.vodgosp.te.ua/ - Назва з екрана.

13. Хмельницьке обласне управління водних ресурсів [Електронний ресурс] : [Веб-сайт]. - Режим доступу : http://vodgosp.km.ua/ - Назва з екрана.

14.Хромов С. П. Метеорологический словар / С. П. Хромов, Л. И. Мамонтова. - Ленинград : Гидрометеоиздат, 1974. - $568 \mathrm{c}$.

15. Чорна Г. А. Флора водойм і боліт Лісостепу України. Судинні рослини / Г. А. Чорна. - К. : Фітосоціоцентр, 2006. - $184 \mathrm{c}$.

16. Kłosowscy S. i G. Flora Polski. Rośliny wodne i bagienne / Stanisław i Grzegorz Kłosowscy. - Warszawa : MULTICO Oficyna Wydawnicza, 2006-2007. - 333 p. 
Михалюк Илона, Чопик Владимир. Изменения климата как угроза для флоры водных макрофитов Северного Подолья. В статье исследуется взаимосвязь между изменениями климата и видовым разнообразия флоры макрофитов Северного Подолья. Установлено, что устойчивое повышение температуры воздуха, сопровождающееся уменьшением количества осадков, вызывает снижение уровня воды в водоемах, а в некоторых случаях и их пересыхание. Проанализированы действие климатических факторов на изменение количества водоемов Северного Подолья и сделан вывод, что при таких метеорологических условиях через 200 лет на исследуемой территории пересохнет 60 водоемов. Сравнивается гидрофильная флора Украины и Польши с помощью определения коэффициентов сходства Жаккара и Сёренсена. По результатам вычислений установлено, что гидрофильные флоры, которые располагаются географически близко друг к другу, обладают высокими показателями сходства.

Ключевые слова: изменение климата, динамика, сравнения, гидрофильная флора, Северное Подолье, Кременецкий район.

Mykhalyuk Ilona, Chopyk Vladimir. Changing of Climate as Threat for Flora Aquatic Macrophytes of Northern Podillya. In the article is research the relationship between climate change and species diversity of flora of macrophytes of Northern Podillya. Established that the steady increase of air temperature, accompanied by a decrease of rainfall, causes reduction of water level in reservoirs and sometimes causes their drying. Hure is analyzed the effect of climatic factors on the change of the number of reservoirs in Northern Podillya and concluded that 60 reservoirs will dry after 200 years inthe investigated area if tare into accaunt such meteorological conditions. The comparison of hydrophilic flora of Ukraine and Poland with the helpof determining similarity coefficients of Zhakkara and Sorensen was made. The results of calculations found that hydrophilic flora that are geographically close to each other, marked by high levels of similarity.

Key words: climate changes, dynamics, comparison, hydrophilic flora, Northern Podillya, Kremenets district.

Стаття надійшла до редколегії 14.10.2015 p.

УДК $581.526(477.81)$

\section{Віктор Онищенко, Олена Прядко, Тетяна Андріснко}

\section{Рослинність ділянки Переброди Рівненського природного заповідника}

Представлено 43 геоботанічні описи. Здійснено їх інтерпретацію з використанням підходів флористичної класифікації рослинності. Вони належать до шести класів, 12 союзів і 19 асоціацій. Найбільша кількість описів належить до класу Scheuchzerio-Caricetea. Особливу увагу приділено синтаксономії лісових мезотрофних боліт.

Ключові слова: Полісся, болотна рослинність, лісова рослинність, класифікація, Україна.

Постановка наукової проблеми та ії значення. Опис фітоценотичної різноманітності територій із наступною класифікацію зібраного матеріалу є центральним напрямом геоботаніки. Найважливіший метод збору матеріалу - виконання повних геоботанічних описів, у ході яких на ділянці, що описується, реєструють усі види вищих рослин. Особливо детально вивчаються природно-заповідні території, насамперед заповідники. Раніше нами опубліковано матеріал стосовно ділянки Сомино Рівненського природного заповідника [6].

Мета статті - охарактеризувати рослинність ділянки Рівненського природного заповідника Переброди.

Виклад основного матеріалу й обгрунтування отриманих результатів дослідження. Рівненський природний заповідник загальною площею 42288,7 га розміщений у північній частині Рівненської області. Він складається з чотирьох великих ділянок - Білоозерської, Сомино, Сира Погоня та Переброди. Ділянка Переброди має загальну площу 13460 га, у т. ч. Північне лісництво - 7565 га, Старосільське - 5895 га. Координати центру Північного лісництва $-51,716^{\circ}$ північної широти й

(C) Онищенко В., Прядко О., Андрієнко Т., 2015 